\title{
Czy człowiek zniewolony nałogiem może przystępować do Eucharystii?
}

Życie w XXI wieku nabrało szczególnego tempa. Współcześnie z powodu przemian cywilizacyjnych obserwujemy mocniejsze niż dotychczas osłabienie pozycji rodziny, wzrasta liczba ludzi będących na emigracji zarobkowej. To wszystko owocuje niestety licznymi rozwodami, rozbiciem rodzin, problemami socjologicznymi. Wiele osób doświadcza coraz częściej osamotnienia, wyobcowania, smutku, depresji, nie radząc sobie z życiem i jego problemami. Na skutek wspomnianej izolacji i zagubienia ludzie młodzi, ale nie tylko, wchodzą na drogę różnorakich uzależnień. Chodzi zarówno o uzależnienia chemiczne: od papierosów, alkoholu, narkotyków, dopalaczy, jak i o uzależnienie od różnorakich zachowań, takich jak: ciągłe korzystanie z gier komputerowych, nieograniczone czasowo korzystanie $z$ Internetu, uprawianie hazardu, pracowanie, wyuzdane zachowania seksualne, robienie zakupów, jedzenie itd. ${ }^{2}$

1 Kapłan Archidiecezji Przemyskiej, ukończył studia magisterskie w Przemyślu w 2010 roku, pracował jako wikariusz w parafii Dubiecko i Strachocina. Od 2014 roku podejmuje studia lic - dr na Papieskim Uniwersytecie Jana Pawła II w Krakowie. W 2015 roku uzyskał tytuł mgr lic. z teologii moralnej, specjalizacji - bioetyka.

2 Por. M. Dziewiecki, Nowoczesna profilaktyka uzależnień, Kielce 2001, s. 5-6. 
Problemem uzależnień zajmują się często psychologowie i terapeuci uzależnień, oferując różne metody psychoterapii, socjoterapii lub farmakoterapii. Istotnym jest, aby na powyższy problem spojrzeć równocześnie od strony teologii moralnej. Należy zauważyć, że dla człowieka religijnego, a przy tym zniewolonego nałogiem, w naszym wypadku nałogiem alkoholizmu, niezbędne jest korzystanie z sakramentów, które stanowią skuteczne lekarstwo dla duszy i dla ciała, pomagające wyjść człowiekowi z największego grzechu. Sakramenty przynoszą owoc w duszach tych, którzy je przyjmują z odpowiednią dyspozycją (Katechizm Kościoła katolickiego [dalej: KKK], 1131). Za Jimem McManusem możemy powiedzieć, że dają one życie, a „to życie nas uzdrawia, uzdrawia naszego ducha i psychikę, a nawet ciało, albowiem Duch Święty dotyka całej naszej istoty: duchowej, psychicznej i fizycznej"3.

Koniecznym zatem w terapii mającej wyprowadzić człowieka z uzależnienia jest jego spotkanie z Bogiem. Czy jednak nałóg nie sprawia, że człowiek staje się niegodnym przystąpienia do Eucharystii? Jak zatem spojrzeć na człowieka będącego w nałogu?

Aby odpowiedzieć na powyżej postawiony problem, w pracy najpierw zostanie przedstawiona nauka o aktach ludzkich. Pozwoli to spojrzeć na temat nałogu alkoholowego od strony przeszkód ograniczających dobrowolność aktu człowieka. W ten sposób będziemy w stanie określić winę moralną i dyspozycje człowieka do przyjęcia Eucharystii. W kolejnym etapie przedstawiony zostanie sakrament Eucharystii jako pomoc i lekarstwo na drodze wyjścia z uzależnienia. W ostatniej odsłonie ukażemy modlitwę, czyli osobistą relację z Bogiem, jako drogę do pokonania nałogu. Relacja ta stawia człowieka w prawdzie o swoich słabościach, uświadamia potrzebę przemiany swego życia, daje pewność, że Bóg nie odwraca się od grzesznika, ale

3 J. McManus, Uzdrawiająca moc sakramentów, tłum. H. Bramska, Warszawa 1990, S. 12. 
pragnie jego przemiany, toteż otwiera przed nim możliwość korzystania ze swoich darów.

\section{Pojęcie aktu rozumnego}

Człowiek jest szczególną istotą, stworzoną na obraz i podobieństwo Boga (por. Rdz 1, 26-27). Stwórca, dzieląc się z nim własnym tchnieniem, wyposażył go oprócz materialnego ciała w nieśmiertelną, niewidzialną duszę. Chciał On, by człowiek bytował jako istota racjonalna, toteż obdarzył go rozumem i wolną wolą, aby mógł wybierać i decydować sam o swoim losie. Tym samym człowiek jest zdolny do poznania dobra i zła. To istota ukierunkowana na cel. Tylko tak stworzony jest zdolny do aktu rozumnego, który obejmuje wszystkie akty pochodzące od woli człowieka, wprawione w działanie poprzez poznanie dobra, celu ukierunkowanego na skutek $^{4}$.

Aby zaistniał akt rozumny, niezbędne są działania zarówno woli, jak i poznania rozumowego. To poznanie jest pierwszym elementem skłaniającym wolę do działania; bez niego nie może go rozpocząćs.

Jak podaje ks. Tadeusz Ślipko:

obok aktów rozumnych w sferze działalności człowieka występują również nader liczne akty nierozumne (zwane też aktami człowieka, aktami nieświadomymi). Charakteryzują się one tym, że pochodzą sprawczo od innych władz człowieka bez udziału jego rozumu i woli, czyli bez jego świadomości, albo przynajmniej udziału woli ${ }^{6}$.

4 Por. T. Ślipko, Zarys etyki ogólnej, Kraków 2004, s. 74.

5 W historii myśli filozoficznej powstała koncepcja woluntarystyczna, według której wola jako dążenie uprzedza poznanie, określa pranaturę rzeczy. Przedstawicielem tej koncepcji był A. Schopenhauer.

6 T. Ślipko, Zarys etyki ogólnej, dz. cyt., s. 75. 
W przypadku nałogu alkoholowego, jak i każdego innego, mamy do czynienia z sytuacją, gdy czyny wykonywane są wprawdzie świadomie, ale poprzez różne sytuacje życia człowiek zatracił ich rozumny charakter. Przyczyny zewnętrzne sprawiły wyłączenie działania rozumu i woli lub jednej z tych władz i człowiek to, co złe, uznał za normalne.

Aby dogłębniej zrozumieć podejście etyki chrześcijańskiej do osób uzależnionych, niezbędne jest wprowadzenie podziału aktu rozumnego na wolny i konieczny.

Akt rozumny konieczny zachodzi wówczas, kiedy wola zostaje zdeterminowana do działania specyficzną naturą określonego dobra, którym jest dobro nieskończone, czyli Absolut.

Człowiek w tym akcie, poznając Boga, pragnie być jak najbliżej Niego. Wola nastawiona na dobro od początku pragnie dobra najwyższego. Nie jest niczym zdeterminowana, dąży do swojego celu, jakim jest jej Stwórca. Wyraża ostateczny sens dążenia istoty rozumnej ${ }^{7}$.

Akt wolny to akt

w którym wola niekrępowana przez przeszkody zewnętrzne ani niepoddana przymusowi działania według praw przyrody [...] dokonuje wyboru określonego dobra spomiędzy kilku poznanych możliwości działania.

Akt ten nazywany jest także aktem dobrowolnym, ludzkim czy świadomym. Akty owe pozostają jednak pod wpływem różnych motywów, uwarunkowań somatycznych, społecznych i psychicznych ${ }^{8}$. $\mathrm{Z}$ problemem nałogu mamy zatem do czynienia, gdy czynniki te

7 Por. T. Ślipko, Zarys etyki ogólnej, dz. cyt., s. 76.

8 Por. T. Ślipko, Zarys etyki ogólnej, dz. cyt., s. 77. 
nakładają na wolę konieczność działania. Są to tzw. przeszkody aktu ludzkiego. Działając na określony akt ludzki, utrudniają funkcjonowanie rozumu lub woli, a nawet całkowicie je uniemożliwiają. Tym samym akt przestaje być świadomym, staje się zaś aktem niedobrowolnym lub częściowo świadomym. Wystarczy, że jedna z władz człowieka, rozum lub wola, doznają jakiegoś ograniczenia, a akt traci już charakter aktu w pełni świadomego. Tym samym „następuje równocześnie nadwyrężenie etycznej sprawności człowieka w jego wykonaniu, w ślad za czym idzie umniejszenie jego odpowiedzialności"'.

W świetle powyższych rozważań, dochodz b. ąc do problemu nałogu w akcie wolnym, należy przywołać naukę Kościoła dotyczącą grzechu. KKK podaje, że

grzech jest wykroczeniem przeciw rozumowi, prawdzie, prawemu sumieniu; jest brakiem prawdziwej miłości względem Boga i bliźniego z powodu niewłaściwego przywiązania do pewnych dóbr. (KKK 1846)

Następnie objaśnia różnicę pomiędzy grzechem ciężkim a lekkim. Aby grzech był śmiertelny, muszą jednocześnie wystąpić trzy warunki: „Grzechem śmiertelnym jest ten, który dotyczy materii poważnej i który nadto został popełniony z pełną świadomością i całkowitą zgodą” (KKK 1857). „Grzech śmiertelny wymaga pełnego poznania i całkowitej zgody. Zakłada wiedzę o grzesznym charakterze czynu, o jego sprzeczności z prawem Bożym. Zakłada także zgodę na tyle dobrowolną, by stanowił on wybór osobisty" (KKK 1859). W przypadku osoby uzależnionej od alkoholu mamy do czynienia $\mathrm{z}$ aktem wolnym, ale i ograniczonym. Człowiek wie, że dany czyn jest grzechem, lecz nie jest w stanie się mu przeciwstawić; podejmuje walkę 
ze swoją słabością, nie jest jej obojętny, to zmniejsza wartość jego grzechu $^{10}$.

Rozpatrując pojęcie nałogu od strony moralnej, warto zatrzymać się nad tematem wrodzonych skłonności. Jest to pociąg do wykonywania jakiejś czynności, nastawienie woli człowieka w kierunku konkretnego działania. W parze $\mathrm{z}$ tą skłonnością idzie zazwyczaj przeżywanie pewnych stanów emocjonalnych. Obok skłonności istnieją jeszcze tzw. nawyki. Poprzez częste popełnianie pewnych aktów osiąga człowiek stałą gotowość woli do ich ponawiania. Gdy nawyki są dobre, rozwijają się cnoty, gdy zaś mamy do czynienia ze złymi nawykami, mówimy o nałogach. Istotnym i mającym wpływ na ocenę moralną jest fakt, czy w pierwszych fazach nabywania nałogu człowiek był świadomy następstw takiego działania, czy też popadł w uzależnienie bez woli i wiedzy. Jeżeli wpadł w nałóg świadomie, to rozumność kolejnych aktów ulega umniejszeniu. Grzechem był akt narażenia się na dany nałóg. Każdy kolejny, powielony akt jest umniejszony, a nawet niekiedy całkowicie skrępowany, jest grzechem powszednim. Jeszcze inaczej przedstawia się sprawa w przypadku nałogów niedobrowolnych, inaczej bezwiednych. Zmniejszają one winę grzechu lub całkowicie ją znoszą ${ }^{11}$.

Teologia moralna dodaje, że nie wszystkie nałogi w identyczny sposób działają na władze duchowe człowieka. Nałogi tzw. organiczne (pijaństwo i rozpusta) przyćmiewają w sposób szczególny działanie rozumu i woli człowieka. Inne to tzw. nałogi duchowe, które nie zakłócają tak mocno psychiki człowieka, stąd łatwiej jest się im przeciwstawić ${ }^{12}$.

Z powyższych rozważań wynika, że człowiek będący w nałogu alkoholizmu może przystąpić do sakramentu Eucharystii. Popełniane przez niego czyny należy traktować w kategorii grzechu powszedniego.

Podane stwierdzenia zawarte są w kolejnych punktach KKK, 1846-1869.

Por. T. Ślipko, Zarys etyki ogólnej, dz. cyt., s. 90-91.

Por. T. Ślipko, Zarys etyki ogólnej, dz. cyt., s. 90-91. 
Sam sakrament Eucharystii może stać się dla takiego człowieka ogromną pomocą.

\section{Eucharystia lekarstwem dla osoby uzależnionej}

Pośród licznych określeń, jakie Kościół używa w odniesieniu do Eucharystii, znajdujemy stwierdzenie mówiące, że jest ona ukoronowaniem wiary chrześcijańskiej i wszystkich innych sakramentów. W Przenajświętszym Sakramencie zawiera się całe dobro duchowe Kościoła, uobecnia się w nim sam Chrystus, w którego wyznajemy wiarę ${ }^{13}$.

Dla kogo zatem jest pozostawiony ten wielki dar? Eucharystia przeznaczona jest dla ludzi ochrzczonych, którzy znajdują się w chwili jej przyjęcia w stanie łaski uświęcającej. Jeśli człowiek jest świadomy popełnienia grzechu ciężkiego, czyli w sposób świadomy i dobrowolny w poważnej materii obraził Boga, nie może przystąpić do Komunii Świętej bez wyznania wcześniej wszystkich swoich grzechów i otrzymania rozgrzeszenia w sakramencie pokuty. Warto pamiętać o tym, że zachowanie wymienionych warunków jest konieczne do tego, aby Komunia Święta przyniosła owoce. Niegodne przystępowanie do niej nie tylko nie sprowadza oczekiwanych łask, ale także jest jednym z najpoważniejszych grzechów (por. KKK 1391). Święty Paweł w Pierwszym Liście do Koryntian stwierdza bardzo dosadnie:

Ilekroć bowiem spożywacie ten chleb albo pijecie kielich, śmierć Pańską głosicie, aż przyjdzie. Dlatego też kto spożywa chleb lub pije kielich Pański niegodnie, winny będzie Ciała i Krwi Pańskiej ${ }^{14}$. (1 Kor 11, 26-27)

Por. Sobór Watykański II, dekret Presbyterorum ordinis, 5 (numer przypisu w KKK: 146).

14 Kodeks prawa kanonicznego [dalej: KPK], kan. 916; por. Kongregacja ds. Kultu Bożego i Dyscypliny Sakramentów, Redemptionis sacramentum, 81. 
Osoby będące w nałogu mogą zatem przystąpić do sakramentu Eucharystii, gdyż ich czyn, waga grzechu, wynika z pomniejszenia świadomości dokonanego aktu. Eucharystia przyjęta przez takich ludzi, z wiarą, ale i świadomością swojej grzeszności, będzie pozytywnie wpływać na ich życie duchowe i fizyczne dzięki owocom płynącym z przyjęcia sakramentu. Komunia Święta pogłębia nasze zjednoczenie z Chrystusem. Pierwszym owocem przyjmowania Komunii Świętej podczas Eucharystii jest głębokie zjednoczenie z Jezusem Chrystusem, który powiedział: „Kto spożywa moje Ciało i Krew moją pije, trwa we Mnie, a Ja w nim" (J 6, 56). Przyjmowanie Komunii Świętej pogłębia i odnawia w nas życie łaski otrzymane na chrzcie (por. KKK 1391-1392).

Już Klemens Aleksandryjski pisał, że boski pokarm nasyca duszę ludzką, sprawia, że sam Logos daje siebie człowiekowi, a ten z Nim się jednoczy ${ }^{15}$. Eucharystia prowadzi do jedności z Bogiem, otwiera człowieka na Boga, co owocuje przemianą jego życia.

Kolejnym owocem płynącym z przyjmowania Eucharystii, jak zauważają ojcowie Kościoła, jest uczestnictwo w nieśmiertelności Pana. Kto ją spożywa, zasługuje na szczęście wieczne. Eucharystia pomaga także w drodze do nieśmiertelności. Jest środkiem, który oczyszcza człowieka od zepsucia i złych cielesnych żądz. Eucharystia „oczyszcza ludzi, którzy ją przyjmują, usuwa z ludzi to, co złe, i nasyca ich tym, co dobre, nasyca Duchem człowieka"16.

Eucharystia przynosi człowiekowi wzrost duchowy w jego życiu chrześcijańskim. Klemens Aleksandryjski stwierdził, że to my winniśmy poskramiać nasze namiętności, natomiast Najświętszy Sakrament, Jezus obecny w naszym sercu, ofiaruje nam możliwość takiego działania, daje moc, bez której byłoby ono bezskuteczne. Pisał też, że

Por. F. Drączkowski, Eucharystia - nieustanne dziękczynienie według Klemensa Aleksandryjskiego, [w: Eucharystia-miłośći dziękczynienie. Praca zbiorowa, red. W. Słomka,

A. J. Nowak, Lublin 1992, s. 43-51 (Homo Meditans, 9). 
należy „Jego, Jezusa, jeśli to możliwe, przyjmując, umieścić w sobie samym i Zbawcy ofiarować swe serce, abyśmy mogli ujarzmić namiętności ciała"17.

KKK w kolejnym punkcie dotyczącym owoców płynących z Eucharystii stwierdza:

Komunia chroni nas przed grzechem. Ciało Chrystusa, które przyjmujemy w Komunii, jest „za nas wydane”; Krew, którą pijemy, jest „wylana za wielu na odpuszczenie grzechów”. Dlatego Eucharystia nie może jednoczyć nas z Chrystusem, nie oczyszczając nas równocześnie z popełnionych grzechów i nie zachowując nas od grzechów w przyszłości. (KKK 1393)

Zatem Eucharystia jest szczególnym darem zwłaszcza dla osób trwających jeszcze w jakimś nałogu. Dodaje ona siły do walki i zachowuje przed kolejnymi upadkami.

Eucharystia przynosi pokrzepienie i umocnienie wiary, tym samym dźwiga człowieka z jego wad, podnosi i odnawia:

Rozum staje się bardziej wolny, a wola wsparta łaską Bożą staje się silniejsza i coraz bardziej konsekwentna w realizowaniu prawa miłości. Ta swoista wewnętrzna integracja prowadzi do pokoju ducha i oddziałuje na wszystkie sfery życia człowieka. To przywrócenie ładu jest możliwe dzięki oczyszczającej mocy Eucharystii, która gładzi nasze grzechy powszednie. Uzdrawia to naszą duszę, uspokaja człowieka i wytwarza w człowieku poczucie siły, wolności; wprowadza do serca pokój i staje się podstawą radości. [...] Kto dobrze przeżywa każdą mszę św., nie jest skory po opuszczeniu świątyni do zapomnienia o Bogu, do powrotu do grzechu ${ }^{18}$.

17 Cyt za: F. Drączkowski, Termin „eucharistia” w pismach Klemensa Aleksandryjskiego, „Vox Patrum" 7 (1987) z. 12-13, s. 73-86.

18 A. Herba, Owoce Eucharystii, „Tygodnik Katolicki Niedziela” 2005 nr 7. 
Eucharystia od zawsze postrzegana była jako lekarstwo dla słabego człowieka. Papież Innocenty III zauważył, że sakrament ten gładzi grzechy powszednie, a zarazem chroni przed śmiertelnymi. Święty Tomasz z Akwinu, powołując się na to stwierdzenie, uwypuklił w Eucharystii dwa momenty: sam sakrament i rzeczywistość, jaką on realizuje. Jak podaje, którykolwiek z tych momentów weźmie się pod uwagę, można dostrzec, że Eucharystia odpuszcza grzechy powszednie. Sakrament ten nazywany pokarmem jest niezbędny ciału, on daje naturalne ciepło, tracone codziennie. Dzień w dzień ponosimy straty w sferze duchowej poprzez grzechy powszednie. Eucharystia gładzi te grzechy, jest, jak powie Święty Augustyn, „lekarstwem na codzienną niemoc"19.

\section{Modlitwa i więź z Bogiem drogą ku wolności}

Modlitwa od zawsze towarzyszyła życiu ludzi, którzy wyznawali wiarę w jakieś najwyższe bóstwo. Stanowi ona centralny akt pobożności w każdej religii. Jest najpełniejszym wyrazem i wyznaniem wiary każdego człowieka ${ }^{20}$.

Po modlitwę sięgał człowiek w codziennych momentach swojego życia, ale przede wszystkim w obliczu różnych problemów, chorób, kiedy dotykało go cierpienie czy jakieś zniewolenie. Wiara w to, że Jezus żyje i działa swoją Boską mocą, uzdrawia i uwalnia istotę ludzką z jej niemocy, jest obecnie równie silna, jak w czasach apostolskich. Dziś niezwykłej mocy modlitwy wielu doświadcza poprzez różne ruchy ewangelizacyjne, seminaria Odnowy w Duchu Świętym, licznie

Św. Tomasz z Akwinu, Suma teologiczna, t. 28, Eucharystia, tłum. S. Piotrowicz, http://www.katedra.uksw.edu.pl/suma/suma_28.pdf (22.11.2014). 
organizowane kursy Alfa, Filipa, a także poprzez msze święte z modlitwą o uzdrowienie i uwolnienie.

Wiara w moc uzdrawiającą modlitwy w religii chrześcijańskiej istniała od zawsze. Przyjmuje się, że uzdrawia ona całego człowieka. Dotyka najpierw jego ducha, uzdrawia go wewnętrznie, leczy $\mathrm{z}$ różnych zranień, wyzwala $\mathrm{z}$ niemocy grzechu. Uwalnia od zniewoleń czysto szatańskiego działania, od nękania człowieka jego codziennymi nałogami, sięga aż po egzorcyzm - specjalną formę odcięcia się od Złego, który opętał duszę. Taką formę modlitwy stosował sam Jezus Chrystus i do dziś w Jego imię podobnie czynią egzorcyści ${ }^{21}$.

W starożytności chrześcijańskiej ojcowie Kościoła w nałogowcach, konkretnie np. w alkoholikach, widzieli prawdopodobnie ludzi zniewolonych przez demona, stąd odsyłano ich do egzorcystów ${ }^{22}$. Nałóg alkoholowy jest pewnym zniewoleniem, którego źródeł należy szukać nie tylko w genetycznych skłonnościach czy sytuacjach społecznych.

Wielu naukowców zajmujących się problemem uzależnienia alkoholowego stwierdza, że oprócz wymiaru fizjologicznego, psychicznego i społecznego, o których piszą terapeuci, występuje tu także wymiar moralny, religijny oraz duchowy. Pan Jezus nauczał: „Każdy, kto popełnia grzech, jest niewolnikiem grzechu [...]. Jeżeli więc Syn was wyzwoli, będziecie rzeczywiście wolni” (J 8, 34. 36). Ludzie uzależnieni, trwając w czynnym stadium nałogu, czyli ciągle sięgając po alkohol, tak naprawdę są nałogowymi grzesznikami. Oczywiście, jak zauważyliśmy w pierwszym punkcie pracy, ze względu na ich

21 Por. K. Leśniewski, „Nie potrzebują lekarza zdrowi...”. Hezychastyczna metoda uzdrawiania człowieka, Lublin 2006, s. 7-1; Z. Lityński, Uzdrowienie duchowe podstawa wszelkiego uzdrowienia, Centrum Formacji Odnowy w Duchu Świętym „Wieczernik”, Magdalenka 2007, s. 4-5.

22 Por. E. Staniek, Dobra Nowina w pogańskim świecie. Rekolekcje dla kapłanów i nie tylko, Kraków 2011, s. 215-216. 
zniewolenie obniża się ich odpowiedzialność moralną. Jednak obniżenie odpowiedzialności nie rozwiązuje jeszcze problemu, który pozostaje nadal.

Wygląda to nieco podobnie jak w przypadku osób borykających się z nałogową masturbacją. W nauczaniu Kościoła traktuje się ją jako zło, poważne nieuporządkowanie, ze względu na wykorzystywanie narządów płciowych poza kontekstem miłości małżeńskiej, niezgodnie z ich celowością. Pomimo to z powodu niedojrzałości emocjonalnej, stanów lękowych, nabytych przyzwyczajeń czy innych czynników psychicznych lub społecznych odpowiedzialność moralna może być tutaj obniżona lub nawet zniwelowana do minimum (KKK 2352).

Literatura poświęcona problematyce uzdrowienia ludzi zniewolonych nałogiem alkoholizmu zwraca uwagę na istotne elementy, które powinny występować u jednostek proszących o uzdrowienie. Są to: uznanie własnej słabości, korzystanie z wszelkich możliwych czynników naturalnych pomagających $\mathrm{w}$ wyjściu $\mathrm{z}$ nałogu, wiara w miłosierdzie i wszechmoc Boga, ciągła, wytrwała modlitwa do Jezusa, Pana i Zbawiciela, który wybacza i przemienia, adoracja Najświętszego Sakramentu i jak najczęstsze korzystanie z sakramentów. Niebezpieczeństwem w korzystaniu $\mathrm{z}$ tego rodzaju modlitw może być podejście magiczne, traktowanie osób posługujących charyzmatem uzdrawiania jak uzdrowicieli, swoistych bioenergoterapeutów itp. Tymczasem charyzmatyczni kapłani, tacy jak o. Józef Witko, o. dr J McManus, o. E. Tardiff, ks. Jan Reczek, o. dr Joseph Marie Verlinde czy inni, podkreślają, że to przede wszystkim zmartwychwstały, eucharystyczny Jezus jest tym, który na chwałę kochającego Boga Ojca, mocą Ducha Świętego dokonuje uzdrowienia, uwolnienia w każdej właściwie z wiarą przeżywanej Eucharystii, sakramencie pokuty, namaszczenia chorych, podczas adoracji, modlitwy wstawienniczej itp. ${ }^{23}$ łowski, Kraków 2011, s. 33-37. 
Wielu terapeutów zauważa, że osoby uczestniczące w modlitwie o uwolnienie czy uzdrowienie podczas mszy świętej i nie tylko doświadczają wyzwolenia od wewnętrznego przymusu wykonywania nałogowych czynności, ale są zobligowane równocześnie do pracy nad swoim uzależnionym sposobem myślenia. Muszą liczyć się, że modlitwa o uzdrowienie powinna iść zawsze w parze z osobistą pracą nad wadami swojego charakteru, który sprzyjał do tej pory nałogowi. Potrzeba wystrzegać się wad, które do nałogu doprowadziły, jak chociażby egocentryzm, narcyzm, egoizm, pycha. Musi nastąpić izolacja od relacji z osobami, które w nałóg wciągały i o nałogu ciągle by przypominały ${ }^{24}$.

Z modlitwą musi iść w parze chęć głębokiej przemiany myślenia i działania, chęć pracy nad sobą. Bardzo często wymaga to pomocy specjalisty, terapeuty oraz pomocy spowiednika. Bez tego może się zdarzyć, że osoba uwolniona od nałogowych zachowań po jakimś czasie do nich powróci, np. pod wpływem stresu, choroby bądź innej niekorzystnej sytuacji. Nałogowe czynności bardzo często są wynikiem nieumiejętności radzenia sobie z trudnościami życiowymi i pewnym sposobem ucieczki od rzeczywistości. Dlatego też, jeśli osoba nie nauczy się rozwiązywać swoich problemów, to mimo doświadczenia łaski odstawienia czynnego nałogu po jakimś czasie pod wpływem doznawanych niepowodzeń może do niego wrócić. Dawne sytuacje uleczone i uzdrowione pozostają ciągle w pamięci, nie da się wymazać z mózgu człowieka tego etapu życia. Dlatego może on powrócić do nałogu nawet po wielu latach. Uzależnienia takie jak alkoholizm, narkomania czy seksoholizm, a być może także i inne, są chorobami chronicznymi, przewlekłymi i zasadniczo z punktu widzenia neurofizjologicznego nieuleczalnymi ${ }^{25}$.

Por. T. Gorski, M. Miller, Jak wytrwać w trzeźwości? Poradnik zapobiegania nawrotom choroby, tłum. B. Białecka, B. Gawrońska, Warszawa 1995, s. 30-35.

25 Por. G. May, Uzależnienie i łaska. Miłość, duchowość i uwolnienie, tłum. E. Woydyłło, Poznań 1988, s. 116. 
Dla osób chorych i modlących się o uzdrowienie konieczna jest przynależność do jakiejś wspólnoty modlitewnej. Będzie ona modlić się za chorą osobę, a tym samym będzie pomocą duchową i realną na drodze wychodzenia $\mathrm{z}$ uzależnienia. $Z$ pewnością dużym wsparciem są różne ruchy i wspólnoty kościelne, które dziś, prężnie działając, pomagają w modlitwie chorym. Wskazać można tutaj ruchy takie jak np. Katolicka Odnowa Charyzmatyczna, Szkoły Nowej Ewangelizacji, Ruch Światło-Życie czy Droga Neokatechumenalna. Znanych jest wiele ruchów niezwiązanych z Kościołem, które także mogą być doskonałym wsparciem, uzupełnieniem prowadzonej modlitwy za osobę uzależnioną. Są to np. spotkania wspólnot samopomocowych opierających swą działalność na programie 12 kroków, przeznaczone dla osób borykających się m.in. z alkoholizmem, narkomanią, hazardem czy seksoholizmem.

Modlitwa posiada niezwykłą moc, potrafi przemieniać myślenie i serce człowieka. Ale wymaga zaangażowania całej osoby oraz pomocy innych przy długim procesie wychodzenia $\mathrm{z}$ uzależnienia. Człowiek jest istotą złożoną, posiada ciało, sferę psychiczną i duchową. Tylko wtedy, gdy wszystkie sfery będą współdziałać ze sobą, można liczyć na powodzenie $\mathrm{w}$ wyjściu nawet $\mathrm{z}$ najbardziej trudnej życiowej sytuacji.

\section{Zakończenie}

Problem nałogów w dzisiejszym świecie dotyka różnych ludzi. Czynniki, które wpływają na sytuacje naszego życia, uświadamiają, że człowiek musi mieć wsparcie od samego Boga, aby nie zagubić się i nie poranić. Dlatego Bóg, wychodząc naprzeciw słabej ludzkiej naturze, „wyposażył nas” w sakramenty, które jako pokarm duchowy sprawiają, że możemy dojść do wieczności i zostać zbawieni.

Sakramenty zarezerwowane są dla członków wspólnoty Kościoła, wymagają więzi z Bogiem i głębokiej wiary w moc ich działania. Jedne zakładają drugie; aby skutecznie przynosiły w nas owoce, niezbędna 
jest łaska uświęcająca. Grzech niszczy tę łaskę. Gdy człowiek będący w nałogu pragnie przystępować do sakramentów, musi zdawać sobie sprawę, że jest winny skutku trwającego problemu. Grzechem, z którego winien przed Bogiem się oskarżyć na początku drogi przemiany, jest moment wejścia na drogę nałogu. Odpuszczenie tego grzechu sprawia, że może korzystać $\mathrm{z}$ innych sakramentów, a każdy grzech zniewolenia ma już wówczas niższą moralną wartość. Oczywiście, wychodząc z nałogu, warto przy każdej spowiedzi podkreślić i wyznać swój problem jako grzech lekki, oddać i po raz kolejny powierzyć go Bogu. Przystępując zaś do Komunii Świętej, powinno się zaś szczerze żałować każdego, nawet najmniejszego powszedniego grzechu, więc i grzechu nałogu. 